\title{
'Believe in me, and I will too': a study of how teachers' expectations instilled confidence in Grade 10 students
}

\author{
Olivia Johnston $^{1}$ (D) Helen Wildy ${ }^{2} \cdot$ Jennifer Shand ${ }^{2}$
}

Received: 4 July 2021 / Accepted: 24 September 2021 / Published online: 20 October 2021

(c) The Author(s) 2021

\begin{abstract}
Teacher expectation research has continued to establish an association between what teachers expect of their students and what students accomplish academically. These expectations affect students when they are communicated by teachers through differential treatment in the class, but no qualitative research has sought adolescent students' points of view about how they experience teacher expectation effects. This paper presents new research findings that explain how Grade 10 students experienced their teachers' expectations in ways that they reflected impacted their academic outcomes. Classic grounded theory methods were used to develop this new knowledge, which has implications for how teachers are educated for, and practice, interacting with secondary school students. The findings are grounded in data from more than 100 interviews with students and 175 classroom observations in three Western Australian metropolitan public secondary schools. Students' voices are projected, explaining how their teachers convey high academic expectations through classroom interactions that instil confidence in students. The discussion invokes a connection to Bandura's Social Cognitive Theory and its enduring tenants of selfefficacy beliefs and mastery learning experiences.
\end{abstract}

Keywords Teacher expectations - Grounded theory $\cdot$ Student self-efficacy beliefs . Student voice

\section{Introduction}

Teachers' expectations can have powerful effects on student academic attainment and their educational pathways (Papageorge et al., 2020; Wu \& Bai, 2015). The phrase 'teacher expectations' is defined here as the judgements that teachers infer

Olivia Johnston

o.johnston@ecu.edu.au

1 School of Education, Edith Cowan University, Perth, WA, Australia

2 Graduate School of Education, The University of Western Australia, Perth, WA, Australia 
from their knowledge of students about if, when, and what students can achieve academically at school (Good, 1987; Rubie-Davies, 2014). Despite the relevance of teachers' expectations for students' experiences of school, a minority of research in this area has considered students' points of view. Viewpoints of adults and educators have been privileged in the design of research approaches for the study and conceptualisation of teacher expectations.

A range of research methods have reflected this adult-educator focus in teacher expectation research. For example, some research has measured teacher expectations through teachers' ability group recommendations (de Boer et al., 2010; Timmermans et al., 2016), surveying teachers about students' future prospects (Friedrich et al., 2015), or by observations of teachers' differential treatment (Bohlmann \& Weinstein, 2013; Weinstein \& Middlestadt, 1979). Only a small minority of studies about teacher expectations have sought to focus on the students' points of view about their teachers' expectations (Weinstein, 2002). While several studies have included quantitative surveys of students (Bohlmann \& Weinstein, 2013; Chen et al., 2011; Rubie-Davies \& Peterson, 2016), the hypotheses tested still originated from an adult-educator viewpoint. Before the research presented in this paper, Weinstein's (2002) research was still the only qualitative study that included both interviews and observations about how students experienced their teachers' expectations of them.

The research findings presented in this paper are from a project that generated new theory about students' experiences of their teachers' expectations of them. The participants included 25 secondary school students, who were observed interacting with their various learning area teachers across a week of school. The research contributes new substantive theory that explains how students experience teacher expectation effects, including through classroom interactions that instil confidence in students.

\section{Literature about teacher expectations}

The influence and formation of teachers' expectations of their students is a topic with a long history of educational research, beginning even before the infamous Pygmalion study (Merton, 1948; Rosenthal \& Jacobson, 1968). Research has continued to show that teacher expectations can be significantly related to academic outcomes (Gentrup et al., 2020; Papageorge et al., 2020). The effect of teacher expectations is generally accepted to be a significant factor for student learning, with meta-analysis calculating an average effect size of 0.43 (Hattie, 2008). Further meta-analyses of the existing research have quantified the effect, showing that teacher expectations can account for anywhere from 3 to $60 \%$ of variance in student academic outcomes (Brophy \& Good, 1984; Jussim \& Harber, 2005; Jussim et al., 1996). The wide variance in teacher expectation effects reflects a broad range of contextual factors that play a role (Weinstein, 2008), including differences in student and teacher characteristics.

Differences in student characteristics can influence the expectations that teachers form for their students' academic achievement. Students from already disadvantaged backgrounds, such as low socio-economic status (SES) (Alvidrez \& Weinstein, 
1999; Rubie-Davies, 2006) and minority ethnicities (Tenenbaum \& Ruck, 2007; van den Bergh et al., 2010) are more likely to experience teacher expectation effects than their higher SES and majority ethnic group peers. Furthermore, some teachers have more pronounced expectancy effects on their students than others. Teachers' differential behaviour between students communicates their expectations through both verbal and non-verbal messages (Babad \& Taylor, 1992; Rosenthal, 2003). Differential behaviours can include preferential treatment, the work and activities offered, questioning of students, use of praise and criticism, ability grouping, behavioural expectations, offering of assistance, and the amount of student autonomy offered (Babad et al., 1982; Marshall \& Weinstein, 1984; Rosenthal, 1994). Some teachers are prone to developing more stratified expectations of their students than others (Babad et al., 1982; Donohue et al., 2000), which can lead to increased differences in how they behave with different students in the class (Joseph et al., 2016; Le, 2014).

Teachers who use more of these differential behaviours when interacting with students have greater expectation effects on their students than teachers who use fewer differentiating behaviours (Kuklinski \& Weinstein, 2001; Rubie-Davies, 2007). Differential behaviour is to be distinguished from Tomlinson's (2003) notion of differentiation, which is a philosophical approach to teaching and learning that provides variety in learning experiences in appreciation of student diversity (Tomlinson, 2003, 2014). Differential behaviour communicates varying expectations for learning to students and sends them messages about their place on the classroom achievement hierarchy (Weinstein, 2002), which is contrary to the flexibility integral in Tomlinson's model of differentiation (Tomlinson, 2014).

In addition to varying levels of differential behaviours, some teachers communicate expectations of student achievement that are overall 'high' or 'low'. High expectation teachers tend to use differential behaviours less frequently, communicating high expectations to their students by using a facilitative approach, continually monitoring students' progress, giving all students the same opportunities to learn, and encouraging student autonomy (Rubie-Davies et al., 2015; Weinstein, 2002). On the other hand, low expectations teachers ask closed questions, group students inflexibly by ability, use more direct instruction and offer less choice (Rubie-Davies, 2007). Surveys of students have confirmed that students associate these behaviours with teachers' expectations (Rio, 2017; Segedin et al., 2012) and that these teacher behaviours can influence student academic self-concepts (Bohlmann \& Weinstein, 2013; Chen et al., 2011). However, there is very little research that provides qualitative explanation about how teachers' expectations are related to student achievement from the students' point of view.

\section{Students' experiences of their teachers' expectations}

Research has investigated student perspectives of the influence that teachers' expectations have on student academic outcomes, with both quantitative and qualitative research findings that teacher expectations can influence students' own beliefs about their capacity to succeed at school (Bohlmann \& Weinstein, 2013; Rubie-Davies, 2008). Students can be astute observers of their teachers' expectations of them 
(Wong, 2014), even at the primary school level (Le, 2014; Weinstein, 2002). However, Weinstein's research is the only study to include deep qualitative exploration of students' perspectives of their teachers' differing expectations (Weinstein, 2002, 2008; Weinstein \& Worrell, 2016). Her work (2002) included observation and interviews of primary school students in the United States, developing new knowledge that students saw their position in the classroom hierarchy as more or less static depending on how much differentiating behaviour the teacher used. Consequentially, students who experienced a lot of differential treatment had little hope that their efforts at school would make a difference to their achievement, while students whose teachers used less differential treatment felt their efforts would positively impact on their learning outcomes.

Since Weinstein's work, only one small study from India (Chandrasegaran \& Padmakumari, 2018) has included some qualitative data about students' perceptions of their teachers' expectations, but these were pitted against their educators' perspectives. The students in this study reported a general increase in confidence and feelings of self-worth that resulted in a positive attitude for students, which was attributed to the teachers' feedback, but the data from the students lacked descriptive depth. Further research from Gillborn et al. (2012) has considered how Black Caribbean adults in the United Kingdom recollect their experiences of low teachers' expectations retrospectively and from their current perspectives as parents, reinforcing racialised expectations as a barrier to equity in education. Yet, this research still does not include the perspectives of the students themselves, instead relying on their adult parents to qualify the students' experiences.

Multiple international studies have found that young people continue to find their teachers' expectations relevant for their experiences of schooling and their academic achievement (Andrews \& Gutwein, 2017; Bae et al., 2008; Bishop \& Berryman, 2006; Williams, 2013). However, these studies encountered teacher expectations in their findings while aiming to explore students' experiences at school more generally. Teacher expectations were also found to be relevant in research that set out to study other aspects of students' educational experiences, such as ability grouping (Hallam \& Ireson, 2007). Other than Weinstein's work, no qualitative research has been specifically designed to achieve to research aim of explaining how students experience their teachers' expectations of them, from their perspectives.

Surveys of students and other quantitative approaches used in educational psychology continue to establish how teachers' expectations influence students when students adopt self-perceptions that reflect teachers' expectations (Friedrich et al., 2015; Trusz, 2018). Researchers initially established a theoretical connection between teachers' use of differential treatment, which communicated expectations to influence student "self-concepts" or "self-esteem" (Brattesani et al., 1984; Weinstein et al., 1982). This link between teachers' communication of expectations through differential behaviour and the impact on students' self-confidence has been established further in more recent research (Bohlmann \& Weinstein, 2013; Trusz, 2018). Students' self-beliefs become more congruent with their teachers' expectations when their teachers' use more differential behaviours in the classroom, reflecting how students' perceptions of themselves mediate the teacher expectation effect (Chen et al., 2011; Friedrich et al., 2015). 
Students' role in the teacher expectation effect is pivotal, yet no qualitative research in this area has sought the views of secondary school students to develop new knowledge about how they experience teacher expectation effects. Adolescents can provide a unique perspective as they find themselves at junctions where their educational decisions are directly associated with their future pathways. They also have distinct learning needs, and their maturity can make them more self-aware and reflective in their experiences of their teachers' expectations. They interact with a variety of learning-area teachers in a variety of classrooms, so they experience different teacher expectations that they could contrast.

\section{Research aim}

This study sought to develop substantive grounded theory to explain how students experience their teachers' expectations of them. The main research question was: How do students experience their teachers' expectations for their academic achievement?

\section{Research approach}

To answer the research question, a qualitative research approach based on the theoretical framework of symbolic interactionism was selected as most appropriate. Qualitative research allows research to 'get at' the inner happenings of participants to describe the experiences of the participants (Corbin \& Strauss, 2008; Creswell, 2014), so this suited my study's aim to focus on the meanings constructed by the Grade 10 student participants. The theoretical framework of symbolic interactionism was used to inform the study because teacher expectations are communicated through the symbolic exchanges between teachers and students during classroom interactions (Blumer, 1969; Francis \& Adams, 2019). The study sought to develop new theory about how students experience their teachers' expectations of them, so a framework that acknowledges the importance of social interaction in creating mutually constructed realities was appropriate (Blumer, 1969; Powell, 2014).

Grounded theory was selected as the research approach because it is consistent with the philosophical framework of symbolic interactionism and suitable for the research goal of developing new theory (Corbin \& Strauss, 2008; Handberg et al., 2015). Through grounded theory, a 'web of meaning' was created to reflect the mutual construction of social reality as well as its complexity and interconnectivity (Aldiabat \& Navenec, 2011; Ezzy, 2002). Grounded theory, symbolic interactionism, and the review of the literature about teacher expectations were drawn upon to develop a conceptual framework for this research, in conjunction with the existing literature about teacher expectations. The conceptual framework was designed as a basis for qualitative exploration of the conditions, actions, strategies and tactics, and consequences of students' experiences of their teachers' expectations (Blumer, 1969; Corbin \& Strauss, 2008). Further guiding research questions were developed 
based on the conceptual framework, which were used to develop conversational semi-structured interview questions.

Ethics approval was obtained from the University of Western Australia Human Research Ethics Committee and the Department of Education System Performance Branch. Student participants were recruited from three secondary schools in a Western Australian Metropolitan area with student populations from mid-low average socio-economic status backgrounds. Students who were invited to participate were those who were identified by their peers, teachers, or through my own observation as students who were influenced by their teachers' expectations of them-these students obtained As in some classes but Fs in others and were observed by the researcher, their peers, and/or their teacher to have altered behaviour according to class and teacher. Layered consent was gained firstly through the school principal, then the teachers, students, and parents who were progressively recruited.

Each participant student was followed to a variety of their Grade 10 classes over the course of a week of school, with interviews at the end of each day about their experiences of their teachers' expectations. The classroom observations provided a shared "Appendix A" context for discussion between the students and I (the researcher) during the interviews. A classroom observation tool is presented in "', which was developed from observation tools that have been designed in previous research for observation of teacher expectations in the classroom (Bohlmann \& Weinstein, 2013; Weinstein et al., 1982). All observations were conducted by a single field researcher, with students' confirming instances where expectations had been communicated during the interviews. A total of 100 interviews and 175 classroom observations were conducted across 25 weeks of school with 25 student participants, with 34 different teachers' classes observed. At each school, some of the Grade 10 teachers allowed multiple student participants in their class to be observed, so for example one English teacher allowed eight of her students to be observed in her class over eight weeks (one student per week was observed, one at a time). Each student was observed interacting with at least two different teachers in two different classes to facilitate comparison. The interview schedule (see "Appendix B") included questions that invoked comparison between teachers, which was facilitated by the field researcher observing multiple classes each day.

Interviews were coded separately by the three authors of this paper to establish consistency of the coding and inter-rater reliability. Each interview was transcribed and analysed before returning to the field to collect more data the next day to allow for the grounded theory to develop through theoretical sampling (Corbin \& Strauss, 2008; Glaser \& Strauss, 2017). Theoretical sampling is integral to grounded theory research because it allows the theory to be built iteratively. This type of sampling is purposive and involves the intentional recruitment of participants who will maximize opportunities for the theory to be constructed (Corbin \& Strauss, 2008). By progressively building the theory, the students were involved as we gradually constructed the theory together. A brief example is provided below and a full description of the process used to generate the grounded theory together with the students is available in a separate paper (Authors, 2021).

One example of how the students and I worked together to develop the theory also reflects the data analysis, synthesis, and abstraction process. I was observing 
and interviewing the second student participant, "Curt." I asked Curt how he knew that his teacher had high expectations of him, and he explained that high expectations were communicated when his teacher praised him for "good thinking," by saying "well done." I asked Curt how he responded to the teachers' communication of high expectations and he said it made him feel "good, because I got it right. It means I'm on the right track. He (the teacher) said to all the people who got it, he said 'you guys should do Physics next year" (Curt). ${ }^{1}$ After transcribing the interview with Curt that evening, I coded this data with the open code of "encouragement" in NVivo, which I used to record my data analysis.

After the next day of classroom observations with Curt, I asked him during our interview if the code of "encouragement" was appropriate for what he had described. He confirmed that it was. We used the opportunity to further explore his experience, and he elaborated that the teachers' encouragement "makes me feel smart... when I feel smart, I'm getting everything correct and I get higher marks in the test" (Curt). I coded this next piece of data under the open code of "feeling smart," but Curt had pointed me towards a connection between teachers' encouragement conveying high expectations and his "feeling smart." Later, I would abstract these two open codes into the theoretical code of "increasing student confidence."

By the time I was working with the 12th student participant, more than 200 open codes had accumulated and there was a need to abstract the data into provisional theoretical codes. The codes that Curt's data had developed: "feeling smart" and "encouragement' were synthesised with the codes of "pride," and "self-confidence." The theoretical category of "increasing student confidence" was developed, including negative cases from the open codes of "disappointment" and "embarrassment." The theoretical code was further explored and refined through theoretical sampling and constant comparison with the next student participants, until saturation of the theory was confirmed with the final 3 participants. In grounded theory, saturation occurs when there are no new properties and dimensions of the theory emerging, only data indicators of elements that have already been discovered (Corbin \& Strauss, 2008; Giles et al., 2016). Thus, the grounded theory was complete.

\section{The grounded theory: reconciling with teachers' expectations}

The findings of the research are synthesised in a substantive theory which is a Basic Social Process (BSP) called Reconciling with teachers' expectations. A BSP is a type of grounded theory that explains a fundamental process that occurs in social environments (Glaser, 1978). The BSP of Reconciling with teachers' expectations explains the four-stage process through which students experience their teachers' expectations of them.

Firstly, the students go through the step of 'Appraising', during which they ascertain their teachers' expectations of them. These interactions inform students' 'Responding' to their teachers' expectations during Stage 2. The students'

\footnotetext{
1 Random pseudonyms are used for the 14 participants whose quotes are used in this manuscript so that readers can differentiate between their voices.
} 
responses to the teacher expectations inform their 'Acting' in Stage 3 in ways that they 'Reflect' in Stage 4 are productive or detrimental to their academic outcomes at school. An example of this BSP is explored in the findings below, where students appraise high expectations when teachers convey belief in their capacity to succeed academically. The students respond by feeling encouraged and capable of achieving, which motivates them academically. They give their work effort and experience improved results, which leads to a self-reinforcing cycle of increased achievement.

The next two sections present the research findings according to the four stages. The first two stages and second two stages are reported together since the quotes from students are often illustrative of two stages. Rather than segment the quotes, they are presented together to provide to illustrate the richness of the data in context.

\subsection{Appraising and responding}

The students appraised whether their teachers had high expectations of them during student-teacher interactions that conveyed belief in their capacity to succeed. Student-teacher interactions conveyed high expectations when teachers encouraged students by expressing pride in them, challenging them, and giving them opportunities to succeed.

Students were asked when their teachers had communicated high expectations during the interviews. Their responses included "teachers that notice us doing good," (Adam) "encouraging" (Corey) and "she encourages us" (Jaida). Encouragement was appraised by students as conveying high teacher expectations for their academic achievement by conveying pride in students verbally or non-verbally. For example, Rachel appraised high expectations in how her teacher had assigned a project: "He has high expectations, like he's pretty impressed with all of us. Like I think he is excited to see what we come up with" (Rachel). High expectations were conveyed by teachers that that encouraged students by expressing pride in what they could accomplish.

Other students agreed that their teachers had communicated high teachers' expectations through encouragement when the students understood that their teachers were proud of them. Araya explained how she responded to high teachers' expectations that were communicated through praise positively. She was asked when her teachers had communicated high expectations, and she brought up the example of a teachers' praise when she answered a question correctly in class. She explained that when her teacher...

...was like 'right! You are right on the money!' and 'Wow, you got it in one!' I'm kind of really proud of myself. I'm like-yeah the teacher's proud of me, and that makes me feel good about myself. I get more confident and put up my hand. I also just sort of feel like maybe it's not a sort of hard as it would be before. (Araya)

Araya's appraisal of high teachers' expectations, communicated through encouragement, made her feel proud of herself. Furthermore, her self-efficacy beliefs were improved, and she considers herself to be more likely to experience continued success at learning in that class. Sarah echoed that a teacher had communicated high expectations that made her feel more confident when she praised her success: 
I explained it to her and she was really happy with the overall idea... she was like Yes YES YES! and thrusting her arms.... when she does stuff like that, it actually makes me feel really proud, because you're on the right track, you're going to do good (Sarah).

When Sarah's teacher communicated high expectations by conveying pride in her, Sarah felt proud too. Other students agreed that verbal praise conveyed high expectations, which they responded to by feeling encouraged to engage in subsequent learning because they considered it likely that the outcome would be positive. When teachers were positive about students' capacity to succeed, the students were positive in their approach to the learning too, because they were more confident that they would be successful.

The encouragement that conveyed high teacher expectations to students could be associated with praise in having noticed the students' success, or in terms of encouraging students to engage in challenging learning. Thus, the students appraised high teachers' expectations when their teachers looked back on their successes with pride, but also when their teachers carried this belief forward to share anticipation that the students could also succeed in the future. Belief that the students could achieve in the future was communicated by encouraging students to give effort. For example, the students described how they had experienced high teachers' expectations when teachers said things that them feel more confident that they could succeed at future challenges. For example, Libby remembered a teacher who conveyed high expectations when "...he always says that "I really like that, you're really trying". He says that to every student. It gives you more confidence" (Libby). Araya elaborated that high expectations were communicated when her teacher challenged her: "...when he says, 'I'm trying to make you think!' ...we need to think about it, like find the right answer. He's just like, encouraging us" (Araya). Encouragement to give effort and engage in challenge was experienced by these students as indicative of the teachers' high expectations that they could accomplish difficult learning.

Students often responded positively when high teacher expectations were communicated by teachers who challenged students to succeed at difficult learning. When the teachers encouraged challenge and conveyed a belief that the students could succeed, the students responded by sharing the teachers' belief that they could succeed. Furthermore, they became motivated to manifest this belief. Jaida explained that when teachers "encourage us (students), it makes me feel like I can do it. It makes me want to try" (Jaida). The students' self-efficacy belief towards future learning was in this way improved when teacher communicated high expectations by encouraging and challenging students. Erin explained further when she mentioned that high expectations had been communicated when her teacher challenging her to attempt some "tricky" new work with encouragement, and how she felt when she experienced success:

...it kind of makes you feel good, because I understand it, but it's tricky and new. It makes me feel happy, and good, because like, oh, I get it now, and it will be easier to do the other questions as well (Erin).

Erin responded to her teachers' high expectations by feeling encouraged to keep trying and complete further questions when she experienced success. Her initial success was a result of the teachers' encouragement, which was perceived as 
praise for being able to accomplish a challenging learning task. Erin's mastery led to her approaching further questions with confidence that she would be successful. Because her teacher encouraged her, she felt encouraged, too.

Students like Erin responded positively to teachers who communicated high expectations through assigning challenging learning. However, the challenging learning was presented encouragingly in a way that they reflected allowed them to succeed. They appraised this as communicating high expectations through encouragement, but some challenges were not appraised as high expectations or responded to positively. For example, Sarah invoked a comparison between high teacher expectations in her above example with a scenario where the teacher had:

...he showed like a graph of our grades, and none of ours really moved. It was only like the other classes that moved. The grades went up, and ours did not. It was actually kind of confronting, because our class, like, it was BAD (students' emphasis)... It was kind of, exposing... it was so unfair... whenever the class was doing bad the teacher would be like "oh this is the (highest) class, you're supposed to be good at this!" It was pretty mean (Sarah).

For student like Sarah, the teacher did not communicate high expectations when they compared them unfavourably to other students. She described this as not communicating high expectations, but as "mean". Other students like Brad, Zane and Libby used the word 'mean' to describe teachers who compared them unfavourably with their peers.

Thus, the students appraised high expectations when their teachers encouraged them in their successes and efforts. High expectations were experienced by students whose teachers assigned them challenging learning tasks without comparing them unfavourably to other students. The students responded positively when high teachers' expectations were appraised through actions that improved their confidence, encouraging them to persevere in their learning. The students responded by becoming confident that they could succeed, too.

\subsection{Acting and reflecting}

The students reflected that they would end up doing better in school when their teachers conveyed high expectations that instilled confidence in them. They approached their learning with more positivity and higher self-efficacy beliefs, which they felt improved their academic outcomes. For example, Brad reflected that when his teachers have high expectations:

...I think they just try to push me then, because they know that I can do that, but sometimes I just don't. Instead of just saying, just say I don't want to do my work, then they'll say like "I can see you can do it" and then I end up doing it. I think I do more work when they do that (Brad).

Brad's reflection summarises the students' descriptions of their increased motivation when their teachers conveyed high expectations that increased their confidence. When the teachers communicated high expectations by encouraging them and 
communicating belief in them, they felt like they could do it, so they tried harder and did "more work".

Other students reflected that they persevered in giving difficult learning effort when their teachers had communicated confidence in their capacity to succeed. After describing her response to her teacher's high expectations for a "tricky" learning task (above), Erin was asked how this affected her academic achievement. She explained that "...I have not met it (the teachers' expectation) yet. I probably will soon, but not yet. Just not now" (Erin). Erin was working towards meeting the teacher's high expectations and described her own confidence that she would eventually get there. She attributed her own confidence to the teachers' confidence in her. Other students agreed that when teachers believed they would be able to achieve, they felt motivated. Jessica recalled her teacher challenging her:

... he's like "prove it" and then I have that logic, okay I'll prove it here, then I'll think this is going to work, prove it. So I just sort of clarify how I think, like we had to change to this idea, that won't work, we had to change to this idea, that won't work, so we had to continuously trial and error (Jessica).

Jessica is prepared to persevere to meet her teachers' high expectations, like Erin. These examples illustrate how the students' confidence inspired their motivation to persist when learning was difficult.

Students also described committing more time to their learning when their teachers had instilled confidence in them by communicating high expectations. For example, Jenny described working towards achieving: “...some of them, just like the harder ones, because there's lots of working out that you have to do, I just have to like, it's like time" (Jenny). She explained she "do(es) a lot of work at home" to meet her teachers' high expectations. Her willingness to devote a lot of time to engaging to challenging learning was accredited to her teachers' expectation of success: “...he thinks we probably could do it" (Jenny). Further willingness to devote time to study and schoolwork was described by students as a result of their teachers' high expectations. Ryan described how he would have to do "extra when I get home and stuff" (Ryan) to make sure he understood. The students acted with increased time commitment when their teachers communicated high expectations through confidence.

The students explained that when their teachers communicated high expectations by having belief in their capacity to succeed, they feel confident and "actually try." This phrase was repeated by several students, including Libby who had described increased confidence from her teachers' verbal encouragement (above). She went on to explain that “...it gives you more confidence. If a teacher just doesn't say anything, you just feel like you're not good enough and you don't know how to do it. I actually try (in that class)" (Libby). Libby's negative case of the teacher who does not build confidence emphasises the importance of communicating high expectations to students, who can be susceptible to feeling "not good enough." When students felt confident that they knew "how to do it," they gave their learning authentic effort.

Teachers' high expectations were motivating for students when they adopted their teachers' beliefs in their capacity to succeed. Corey explained that his teachers' praise had "encourage(d) me to do more work. I want to do more." (Corey). When 
the students were motivated by high teacher expectations, they did more. Sarah added that "I like just work to improve every time" (Sarah).

Nadia explained that his was because of increasing self-efficacy belief:

...he would motivate me to do more, I'd be like "oh wow!" And I'd realise that I actually could do more. So it means that in like the next assignments he wouldn't have to tell me, I could just do it, and it would just come naturally, and I wouldn't have to put that extra effort in, like when he helped me with it. So after that it just starting increasing and my grades just kept getting higher (Nadia).

Nadia's quote represents how students' self-efficacy beliefs were improved when their teachers communicated high expectations through confidence, which could lead to a self-perpetuating cycle of continued achievement. For students like Nadia, it was the teachers' high expectations that initiated academic improvements.

However, students did not always respond positively to teachers' communication of high expectations for students' capacity to succeed when it was communicated as disappointment in the students' not fulfilling expectations. This was the case in the example from Sarah in the above section, when she described the teacher as "mean" for pressuring students to do better by comparing them unfavourably to another group. Sarah described this as communicating high expectations, but by using pressure to succeed rather than instilling confidence. Other students agreed that high teachers' expectations only instilled confidence when they were encouraging, not negative. For example, when Rachel was asked to explain when her teacher had communicated expectations for her academic achievement that day, she brought up an interaction where a teacher had been disappointed in her.

I know she's, like, very disappointed. I'm like walk in-didn't happen! When I feel, like, bad or, like, oh-why am I in this situation that I put myself inI'm just, like, - don't think about it. but it probably, like, builds up and then at times I'll think, oh a big sad, and then it will all, like, come up. I feel, like, yeah I'm living in the, like, yeah I'll try hard next year, you know what I mean? (Rachel)

Rachel is describing how her teachers' expectations made her feel as if she didn't measure up, which had disappointed the teacher and led to Rachel being passive about her learning. Rachel explained that her teachers' disappointment made her want to avoid future interactions with the teacher. Furthermore, she was passive about her efforts when her teacher expressed disappointment in her.

These findings show that when expectations were communicated in a context of students having not met expectations, students responded negatively and became passive about their learning. On the other hand, teachers' high expectations that instilled confidence in students were experienced positively by students only when the teachers were encouraging during interactions with students.

Overall, the research findings illustrate how students experienced the influence of their teachers' expectations through the teachers' instilling confidence in them. The teachers' expectations improved the students' learning outcomes when they 
effectively instilled a shared belief in the students' capacity to succeed. The students appraised teachers as having high expectations when the teachers encouraged them and made them feel capable of learning, challenging them to engage in challenging tasks. The students felt that they could succeed and were motivated to persevere when the learning became difficult, which they reflected led to successes in learning. Success empowered the students so that they continued to act in and then acting in ways that they reflected upon as improving academic outcomes. However, when teachers communicated high expectations by emphasising students' lack of success by contrasting them to peers or dwelling on the students' failure to meet high expectations, the students became passive about their learning. Such teachers were appraised as "mean" and did not effectively communicate high expectations that positively impacted on student learning.

\section{Discussion}

The findings of this study explain that students experience high teachers' expectations as instilling confidence in their ability as learners. This finding can be understood with consideration of enduring educational theory, such as that of student self-efficacy beliefs from Bandura (1986) and Dweck's theory of Mindset (Dweck, 2012). The findings also show how some of Weinstein's findings about how primary school students experience their teachers' expectations are exacerbated in the secondary school setting where student confidence is particularly vulnerable (Weinstein, 2002). A discussion of Rubie-Davies' work (2006; Rubie-Davies \& Peterson, 2016) also furthers a situated understanding of the contribution to knowledge and understanding of teachers' expectations provided by this research.

The connection between teachers' expectations and students' self-beliefs about their capacity to succeed at school has been established in previous quantitative research from educational psychology (Tyler \& Boelter, 2008). The research findings presented in this paper provide a student perspective on how teacher expectation effects occur, emphasising the direct effect on student self-beliefs. The students in the study referred to this as "confidence," but their descriptions of the role of verbal encouragement and task mastery are most reminiscent of Bandura's (1986) theoretical construct of self-efficacy belief. Bandura's notion of self-efficacy beliefs are the crux of his enduring Social Cognitive Theory (Bandura, 1986). Student selfefficacy beliefs, in education, are students' perceptions of their own capacity for the organisation and behaviour they need to achieve a particular effect or outcome in their learning (Bandura, 1986; Zimmerman, 2000). The students' self-efficacy about a learning task, for example, will shape their behaviour as they conduct that task.

The findings of the study presented in this paper can be understood through Bandura's theory, reinforcing that when students have high self-efficacy beliefs, they act by "pushing" themselves and "doing extra work" to achieve challenging learning outcomes. Bandura's self-efficacy belief is conceptualised as specific to performance on certain tasks. Teachers can influence students' self-efficacy beliefs positively by providing them with mastery learning experiences, encouragement, and access to 
other students who model the skills and organisation that lead to success (Schunk \& Usher, 2012; Sewell \& St George, 2009). The students in this study experienced teachers who positively influenced their self-efficacy beliefs as communicating high expectations for their learning. This provides an explanation of how students experienced their teachers' expectations of them in ways that influence their achievement at school: through their self-efficacy beliefs.

The study presented in this paper is unique in that it included data about Grade 10 students' experiences of their teachers' expectations across several of their different secondary school classes, explaining how these students were influenced by their teachers' expectations: through classroom interactions that instilled confidence. When teachers provided challenging, but attainable, opportunities for students to experience mastery learning experiences, students regarded this as a characteristic of high expectation teachers and experienced increased confidence and academic attainment. As illustrated in the above examples of students like Sarah and Rachel, a student could experience confidence in learning in one class, but experience feelings of inadequacy in learning in another class. For these students, this was related to how the teachers' expectations were communicated during interactions with the teacher.

Previous research has discussed the notion of subject-specific student self-belief (Marsh et al., 2012), but this has been associated with the learning area itself rather than the teacher. The research presented in this paper shows that when teachers communicated high expectations with encouragement, pride, and challenge, students reacted by embracing challenging learning, "trying really hard" (Libby). However, when teachers communicated high expectations in a way that was comparative and emphasised students' previous failure to meet high expectations, the students responded negatively. They appraised teachers that applied academic pressure in this way as "mean" (Sarah, Libby, Brad, Zane) and became passive about their learning. These findings suggest that student self-efficacy beliefs can become differentiated across learning areas based on varying experiences of teacher expectations.

The student experiences that were illustrated in the findings also reflect how students mindsets and concepts about themselves as learners are related to teacher expectations, which is reminiscent of Dweck's contrasting growth and fixed mindsets about learning (Dweck, 2008). Similar to the primary school students in Rhona Weinstein's (2002) study who experienced a loss of hope and belief in their capacity to change their position in the classroom hierarchy when their teacher communicated low expectations, the students in the study presented in this paper described their experience of giving up on learning in classes where the teacher was appraised communicating expectations framed by contrasting student achievement against one another. When the students were compared unfavourably to their peers, they became passive in their learning. Rubie-Davies' research (2007) affirms that teachers with low expectations group students inflexibly into ability groups. The research presented in this paper suggests that students experience fixed views of ability as detrimental to their confidence.

On the other hand, students felt empowered and confident in their learning with teachers who communicated high expectations. These findings show that Weinstein's research with primary students is also relevant in the context of adolescent 
students. Adolescent students are on the cusp of adulthood and are in the process of developing individual identity and aspiration, so the role of teacher expectations in this process is highly relevant. The findings also elaborate on why interactions that communicate teacher expectations are associated with student academic achievement: through student confidence. Rubie-Davies and her colleagues have also established that high expectations teachers are more likely to give students another try at answering questions and ask for more detail, provide more feedback, and encourage student motivation and autonomy (Rubie-Davies et al., 2015; Wang et al., 2019). These practices communicate high expectations to students, but the research presented in this paper suggests that this is because they communicate a belief in students that students then adopt in their own self-beliefs.

\section{Limitations}

This paper presents the results of a grounded theory study that was conducted at three Schools in the Perth Metropolitan area. The findings are only representative of the group and students under study, and more research would be needed to ascertain the extent to which the substantive theory could be used to develop a formal theory that is generalisable. It was not within this study's aims to create a formal theory that represents all human interactions, because the research aim was to generate a substantive theory. Thus, the study is limited in its generalisability and makes no claims to apply to populations beyond those from which the data were collected. Some readers, however, may find the research or some aspects of it transferable to their own contexts.

\section{Conclusion}

The findings of this study presented in this paper show that students experience teacher expectation effects through the BSP of Reconciling with teachers' expectations when the teacher communicates expectations in ways that instil confidence in students (or fail to do so). The students' beliefs about themselves as learners are shaped by the teacher's communication of expectations for students, so that when the teacher coveys a belief that the student can succeed at school, the student believes it too and acts accordingly.

These findings have implications for teacher education and how teachers prepare for and practice interacting with their students. Teachers who aim to communicate high expectations can adopt the strategies suggested by the students in these findings, including praising and encouraging student success during classroom interactions to instil confidence. Teachers could also adapt these findings to inform how they challenge students to learn in their class, striking the right balance between pressuring students and empowering them. High teacher expectations were only effective in motivating students to act in ways that improved academic outcomes when they were presented without unfavourable comparison. High expectations 
for all students, not just the top performers, were a contingency of positive teacher expectation effects.

The findings of this study add to knowledge about teacher expectations by explaining how teacher expectations can affect student academic outcomes through student confidence. High expectations were communicated when the teachers supported students' accomplishment in challenging learning tasks by questioning them and encouraging their efforts and perseverance, expressing belief that they would succeed. Continued research in education emphasises that mastery experiences and verbal encouragement can shape student self-efficacy beliefs (Hendricks, 2016; Schunk, 2003; Wilson et al., 2014) and that self-efficacy beliefs are associated with improved student outcomes (Honicke \& Broadbent, 2016). The research adds to this knowledge by explaining how teacher expectations influenced student self-beliefs and why this affected their educational outcomes. Interactions where students appraised high teacher expectations improved their self-belief, which led them to act in ways that they reflected promoted academic attainment.

\section{Appendix A: Observation tool}

See Fig. 1.

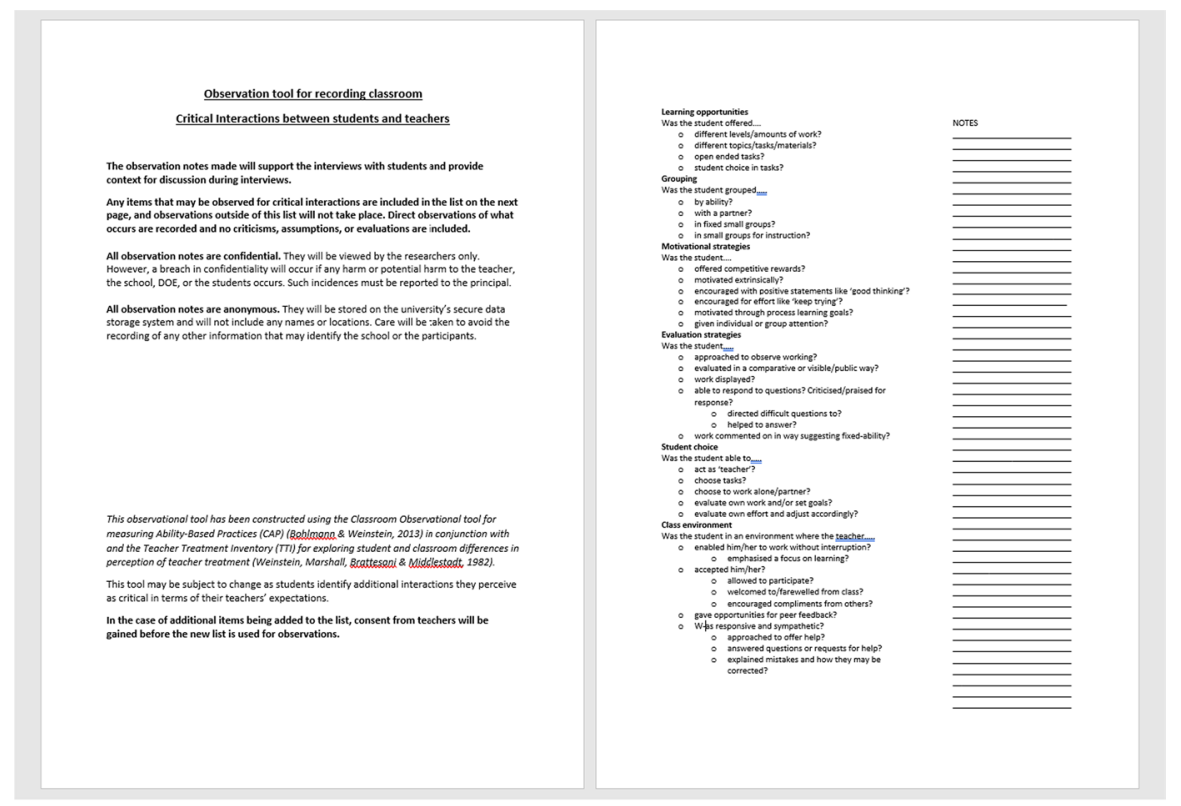

Fig. 1 "Appendix A". 


\section{Appendix B: Interview schedule}

See Fig. 2.

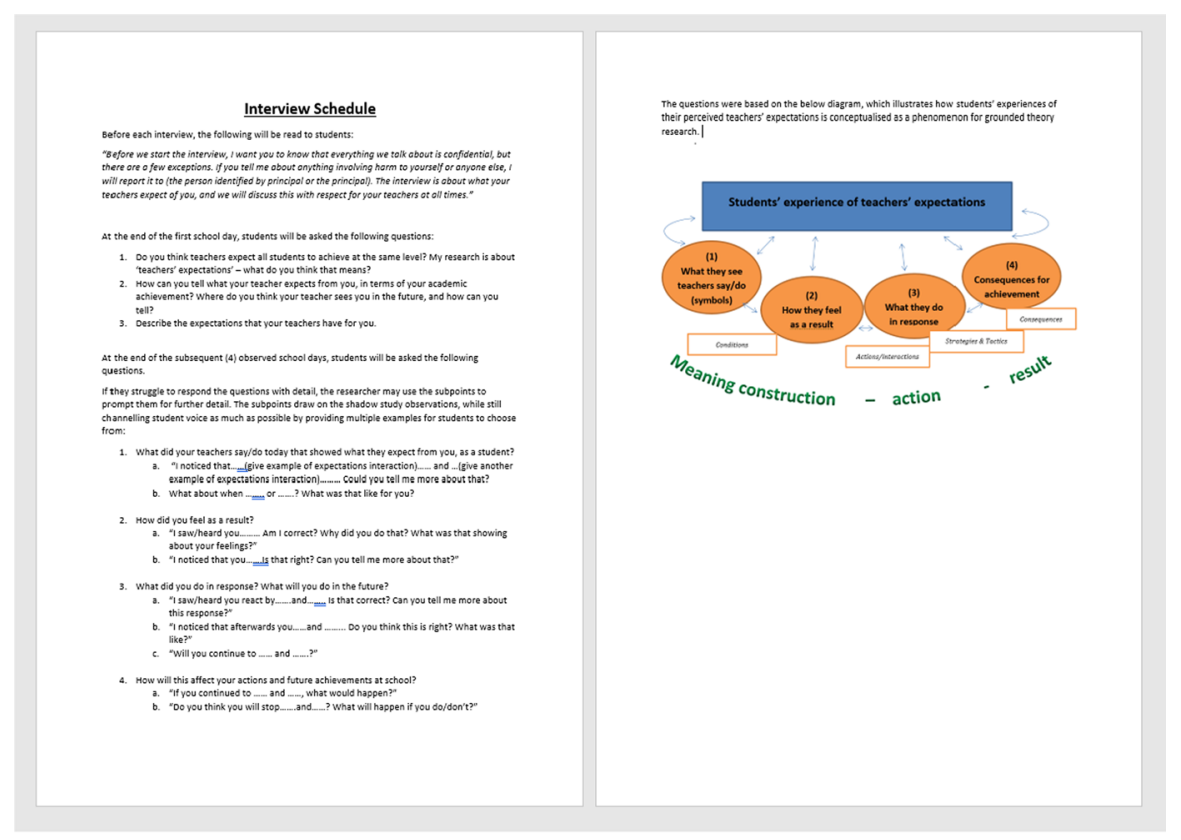

Fig. 2 "Appendix B". 
Acknowledgements This paper was written with support from the Australian Department of Education Research Training Program.

Authors contribution All authors contributed to the study conception and design. Material preparation, data collection and analysis were performed by Olivia Johnston. The first draft of the manuscript was written by Olivia Johnston and all authors commented on previous versions of the manuscript. All authors read and approved the final manuscript.

Open Access This article is licensed under a Creative Commons Attribution 4.0 International License, which permits use, sharing, adaptation, distribution and reproduction in any medium or format, as long as you give appropriate credit to the original author(s) and the source, provide a link to the Creative Commons licence, and indicate if changes were made. The images or other third party material in this article are included in the article's Creative Commons licence, unless indicated otherwise in a credit line to the material. If material is not included in the article's Creative Commons licence and your intended use is not permitted by statutory regulation or exceeds the permitted use, you will need to obtain permission directly from the copyright holder. To view a copy of this licence, visit http://creativecommons.org/ licenses/by/4.0/.

\section{References}

Aldiabat, K. M., \& Navenec, L. (2011). Philosophical roots of classical grounded theory: Its foundations in symbolic interactionism. Qualitative Report, 16(4), 1063-1080. https://nsuworks.nova.edu/tqr/ vol16/iss $4 / 9$

Alvidrez, J., \& Weinstein, R. (1999). Early teacher perceptions and later student academic achievement. Journal of Educational Psychology, 91(4), 731-746. https://doi.org/10.1037/0022-0663. 91.4.731

Andrews, D. J. C., \& Gutwein, M. (2017). "Maybe that concept is still with us": Adolescents' racialized and classed perceptions of teachers' expectations. Multicultural Perspectives, 19(1), 5-15. https://doi.org/10.1080/15210960.2016.126396

Babad, E., Inbar, J., \& Rosenthal, R. (1982). Pygmalion, Galatea, and the Golem: Investigations of biased and unbiased teachers. Journal of Educational Psychology, 74(4), 459-474. https://doi. org/10.1037/0022-0663.74.4.459

Babad, E., \& Taylor, P. J. (1992). Transparency of teacher expectancies across language, cultural boundaries. The Journal of Educational Research, 86(2), 120-125. https://doi.org/10.1080/ 00220671.1992 .9941148

Bae, S., Holloway, S. D., Li, J., \& Bempechat, J. (2008). Mexican-American students' perceptions of teachers' expectations: Do perceptions differ depending on student achievement levels? The Urban Review, 40(2), 210-225. https://doi.org/10.1007/s11256-007-0070-x

Bandura, A. (1986). Social foundations of thought and action. Englewood Cliffs.

Bishop, R., \& Berryman, M. (2006). Culture speaks: Cultural relationships and classroom learning. Huia Publishers.

Blumer, H. (1969). Symbolic interactionism : Perspective and method. Prentice-Hall.

Bohlmann, N. L., \& Weinstein, R. (2013). Classroom context, teacher expectations, and cognitive level: Predicting children's math ability judgments. Journal of Applied Developmental Psychology, 34(6), 288-298. https://doi.org/10.1016/j.appdev.2013.06.003

Brattesani, K. A., Weinstein, R. S., \& Marshall, H. (1984). Student perceptions of differential teacher treatment as moderators of teacher expectation effects. Journal of Educational Psychology, 76(2), 236-247. https://doi.org/10.1037/0022-0663.76.2.236

Brophy, J., \& Good, T. L. (1984). Teacher behavior and student achievement. The Institute for Research on Teaching.

Chandrasegaran, J., \& Padmakumari, P. (2018). The role of self-fulfilling prophecies in education: Teacher-student perceptions. Journal on Educational Psychology, 12(1), 8. https://doi.org/10. 26634/jpsy.12.1.14639 
Chen, Y.-H., Thompson, M. S., Kromrey, J. D., \& Chang, G. H. (2011). Relations of student perceptions of teacher oral feedback with teacher expectancies and student self-concept. Journal of Experimental Education, 79(4), 452-477. https://doi.org/10.1080/00220973.2010.547888

Corbin, J. M., \& Strauss, A. L. (2008). Basics of qualitative research: Techniques and procedures for developing grounded theory (3rd ed.). SAGE Publications.

Creswell, J. (2014). The selection of a research approach. In Research design: Qualitative, quantitative, and mixed methods approaches (pp. 3-24). SAGE Publications.

de Boer, H., Bosker, R. J., \& van der Werf, M. P. C. (2010). Sustainability of teacher expectation bias effects on long-term student performance. Journal of Educational Psychology, 102(1), 168-179. https://doi.org/10.1037/a0017289

Donohue, K. M., Weinstein, R., Cowan, P. A., \& Cowan, C. P. (2000). Patterns of teachers' wholeclass perceptions and predictive relationships between teachers' and parents' perceptions of individual child competence. Early Childhood Research Quarterly, 15(3), 279-305. https://doi.org/ 10.1016/S0885-2006(00)00068-5

Dweck, C. (2008). Mindset: The new psychology of success. Random House Digital, Inc.

Dweck, C. (2012). Mindset: How you can fulfil your potential. Constable \& Robinson.

Ezzy, D. (2002). Data analysis during data collection. In D. Ezzy (Ed.), Qualitative analysis: Practice and innovation (pp. 60-79). Routledge.

Francis, L. E., \& Adams, R. E. (2019). Two faces of self and emotion in symbolic interactionism: From process to structure and culture-and back. Symbolic Interaction, 42(2), 250-277. https:// doi.org/10.1002/symb.383

Friedrich, A., Flunger, B., Nagengast, B., Jonkmann, K., \& Trautwein, U. (2015). Pygmalion effects in the classroom: Teacher expectancy effects on students' math achievement. Contemporary Educational Psychology, 41, 1-12. https://doi.org/10.1016/j.cedpsych.2014.10.006

Gentrup, S., Lorenz, G., Kristen, C., \& Kogan, I. (2020). Self-fulfilling prophecies in the classroom: Teacher expectations, teacher feedback and student achievement. Learning and Instruction, 66(4), 1-17. https://doi.org/10.1016/j.learninstruc.2019.101296

Giles, M. T., De Lacey, M. S., \& Muir-Cochrane, M. E. (2016). Coding, constant comparisons, and core categories: A worked example for novice constructivist grounded theorists. Advances in Nursing Science, 39(1), 29-44. https://doi.org/10.1097/ANS.0000000000000109

Gillborn, D., Rollock, N., Vincent, C., \& Ball, S. J. (2012). 'You got a pass, so what more do you want?' Race, class and gender intersections in the educational experiences of the Black middle class. Race Ethnicity and Education, 15(1), 121-139.

Glaser, B. G. (1978). Theoretical sensitivity: Advances in the methodology of grounded theory. Sociology Press.

Glaser, B. G., \& Strauss, A. L. (2017). Discovery of grounded theory : Strategies for qualitative research, 3rd ed. Routledge.

Good, T. L. (1987). Two decades of research on teacher expectations: Findings and future directions. Journal of Teacher Education, 38(4), 32-47. https://doi.org/10.1177/002248718703800406

Hallam, S., \& Ireson, J. (2007). Secondary school pupils' satisfaction with their ability grouping placements. British Educational Research Journal, 33(1), 27-45.

Handberg, C., Thorne, S., Midtgaard, J., Nielsen, C. V., \& Lomborg, K. (2015). Revisiting symbolic interactionism as a theoretical framework beyond the grounded theory tradition. Qualitative Health Research, 25(8), 1023-1032. https://doi.org/10.1177/1049732314554231

Hattie, J. (2008). Visible learning: A synthesis of over 800 meta-analyses relating to achievement, 1 st ed. Taylor and Francis.

Hendricks, K. S. (2016). The sources of self-efficacy: Educational research and implications for music. Applications of Research in Music Education, 35(1), 32-38. https://doi.org/10.1177/8755123315 576535

Honicke, T., \& Broadbent, J. (2016). The influence of academic self-efficacy on academic performance: A systematic review. Educational Research Review, 17, 63-84. https://doi.org/10.1016/j.edurev. 2015.11.002

Joseph, N. M., Viesca, K. M., \& Bianco, M. (2016). Black female adolescents and racism in schools: Experiences in a colorblind society. The High School Journal, 100(1), 4-25. https://doi.org/10.1353/ hsj.2016.0018

Jussim, L., Eccles, J., \& Madon, S. (1996). Social perception, social stereotypes, and teacher expectations: Accuracy and the quest for the powerful self-fulfilling prophecy. Advances in Experimental Social Psychology, 28(C), 281-388. https://doi.org/10.1016/S0065-2601(08)60240-3 
Jussim, L., \& Harber, K. D. (2005). Teacher expectations and self-fulfilling prophecies: Knowns and unknowns, resolved and unresolved controversies. Personality and Social Psychology Review, 9(2), 131-155. https://doi.org/10.1207/s15327957pspr0902_3

Kuklinski, M. R., \& Weinstein, R. (2001). Classroom and developmental differences in a path model of teacher expectancy effects. Child Development, 72(5), 1554-1578. https://doi.org/10.1111/14678624.00365

Le, M. (2014). The just distribution of educational resources: Children's judgments about differential treatment by teachers (Publication Number 14148) University of California. eScholarship. https:// digitalassets.lib.berkeley.edu/etd/ucb/text/Le_berkeley_0028E_14148.pdf

Marsh, H. W., Xu, M., \& Martin, A. J. (2012). Self-concept: A synergy of theory, method, and application. In S. Harris, T. Graham, C. Urdan, G. McCormick, G. Sinatra, \& J. Sweller (Eds.), APA educational psychology handbook: Theories, constructs and critical issues (Vol. 1, pp. 427-458). American Psychological Association. https://doi.org/10.1037/13273-015

Marshall, H. H., \& Weinstein, R. (1984). Classroom factors affecting students' self-evaluations: An interactional model. Review of Educational Research, 54(3), 301-325. https://doi.org/10.3102/00346 543054003301

Merton, R. K. (1948). The self-fulfilling prophecy. The Antioch Review, 8(2), 193-210.

Papageorge, N. W., Gershenson, S., \& Kang, K. M. (2020). Teacher expectations matter. Review of Economics and Statistics, 102(2), 234-251.

Powell, J. L. (2014). Symbolic Interactionism. Nova Science Publishers, Inc.

Rio, N. (2017). Teacher expectations and ethnicity: Student and teacher perspectives (Publication Number 32245) ResearchSpace. Auckland. http://hdl.handle.net/2292/32245.

Rosenthal, R. (1994). Interpersonal expectancy effects: A 30-year perspective. Current Directions in Psychological Science, 3(6), 176-179. https://doi.org/10.1111/1467-8721.ep10770698

Rosenthal, R. (2003). Covert communication in laboratories, classrooms, and the truly real world. Current Directions in Psychological Science, 12(5), 151-154. https://doi.org/10.1111/1467-8721. t01-1-01250

Rosenthal, R., \& Jacobson, L. (1968). Pygmalion in the classroom. The Urban Review, 3(1), 16-20. https://doi.org/10.1007/BF02322211

Rubie-Davies, C. (2008). Teacher beliefs and expectations: Relationships with student learning. In C. Rubie-Davies \& C. Rawlinson (Eds.), Challenging thinking about teaching and learning (pp. 25-39). Nova Science Publishers.

Rubie-Davies, C. (2014). Becoming a high expectation teacher: Raising the bar. Taylor and Francis.

Rubie-Davies, C., \& Peterson, E. (2016). Relations between teachers' achievement, over- and underestimation, and students' beliefs for Māori and Pākehā students. Contemporary Educational Psychology, 47, 72-83. https://doi.org/10.1016/j.cedpsych.2016.01.001

Rubie-Davies, C., Peterson, E., Sibley, C., \& Rosenthal, R. (2015). A teacher expectation intervention: Modelling the practices of high expectation teachers. Contemporary Educational Psychology, 40(C), 72-85. https://doi.org/10.1016/j.cedpsych.2014.03.003.

Rubie-Davies, C. (2006). Teacher expectations and student self-perceptions: Exploring relationships. Psychology in the Schools, 43(5), 537-552. https://doi.org/10.1002/pits.20169

Rubie-Davies, C. (2007). Classroom interactions: Exploring the practices of high- and low-expectation teachers. British Journal of Educational Psychology, 77(2), 289-306. https://doi.org/10.1348/00070 9906X101601

Schunk, D. H. (2003). Self-efficacy for reading and writing: Influence of modeling, goal setting, and selfevaluation. Reading \& Writing Quarterly, 19(2), 159-172. https://doi.org/10.1080/10573560308219

Schunk, D. H., \& Usher, E. L. (2012). Social cognitive theory. In K. R. Harris, S. Graham, T. Urdan, C. McCormick, G. Sinatra, \& J. Sweller (Eds.), APA educational psychology handbook (Vol. 1, pp. 101-123). American Pyschological Association.

Segedin, L., Peters, S., Asghar, A., Choudry, A., Savard, A., \& Strong-Wilson, T. (2012). Listening to the student voice: Understanding the school-related factors that limit student success. McGill Journal of Education, 47(1), 93-107. https://mje.mcgill.ca/article/viewFile/9084/6875.

Sewell, A., \& St George, A. (2009). Developing efficacy beliefs in the classroom. The Journal of Educational Enquiry, 1(2). https://ojs.unisa.edu.au/index.php/EDEQ/article/view/576.

Tenenbaum, H. R., \& Ruck, M. D. (2007). Are teachers' expectations different for racial minority than for European American students? A Meta-Analysis. Journal of Educational Psychology, 99(2), 253273. https://doi.org/10.1037/0022-0663.99.2.253 
Timmermans, A. C., de Boer, H., \& van der Werf, M. P. C. (2016). An investigation of the relationship between teachers' expectations and teachers' perceptions of student attributes. Social Psychology of Education: an International Journal, 19(2), 217-240. https://doi.org/10.1007/s11218-015-9326-6

Tomlinson, C. (2003). Fulfilling the promise of the differentiated classroom: Strategies and tools for responsive teaching. Association for Supervision and Curriculum Development.

Tomlinson, C. (2014). The differentiated classroom: Responding to the needs of all learners, 2nd ed. ASCD.

Trusz, S. (2018). Four mediation models of teacher expectancy effects on students' outcomes in mathematics and literacy. Social Psychology of Education : an International Journal, 21(2), 257-287. https://doi.org/10.1007/s11218-017-9418-6

Tyler, K. M., \& Boelter, C. M. (2008). Linking black middle school students' perceptions of teachers' expectations to academic engagement and efficacy. Negro Educational Review, 59(1/2), 27-44,125126. https://search.proquest.com/docview/219037863?accountid=14681.

van den Bergh, L., Denessen, E., Hornstra, L., Voeten, M., \& Holland, R. W. (2010). The implicit prejudiced attitudes of teachers: Relations to teacher expectations and the ethnic achievement gap. American Educational Research Journal, 47(2), 497-527. https://doi.org/10.3102/0002831209353594

Wang, S., Rubie-Davies, C. M., \& Meissel, K. (2019). Instructional practices and classroom interactions of high and low expectation teachers in China. Social Psychology of Education, 22(4), 841-866. https://doi.org/10.1007/s11218-019-09507-4

Weinstein, R. (2002). Reaching higher: The power of expectations in schooling. Harvard University Press.

Weinstein, R. (2008). Schools that actualize high expectations for all youth: Theory for setting change and setting creation. Oxford University Press. https://doi.org/10.1093/acprof:oso/9780195327892. 003.0005

Weinstein, R., Marshall, H., Brattesani, K., \& Middlestadt, S. (1982). Student perceptions of differential teacher treatment in open and traditional classrooms. Journal of Educational Psychology, 74(5), 678-688. https://doi.org/10.1037/0022-0663.78.6.441

Weinstein, R., \& Middlestadt, S. (1979). Student perceptions of teacher interactions with male high and low achievers. Journal of Educational Psychology, 71(4), 421-431. https://doi.org/10.1037/00220663.71.4.421

Weinstein, R., \& Worrell, F. C. (2016). Achieving college dreams: How a university-charter district partnership created an early college high school. Oxford University Press.

Williams, R. M. F. (2013). When gray matters more than black or white: The schooling experiences of black-white biracial students. Education and Urban Society, 45(2), 175-207. https://doi.org/10. $1177 / 0013124511406917$

Wilson, H. E., Siegle, D., McCoach, D. B., Little, C. A., \& Reis, S. M. (2014). A model of academic self-concept: Perceived difficulty and social comparison among academically accelerated secondary school students. Gifted Child Quarterly, 58(2), 111-126. https://doi.org/10.1177/0016986214 522858

Wong, M. (2014). Voices of children, parents and teachers: How children cope with stress during school transition. Early Childhood Development and Care, 185, 1-21. https://doi.org/10.1080/03004430. 2014.948872

Wu, C., \& Bai, H. (2015). From early aspirations to actual attainment: the effects of economic status and educational expectations on university pursuit. Higher Education, 69(3), 331-344. https://doi.org/ 10.1007/s 10734-014-9778-1

Zimmerman, B. J. (2000). Self-efficacy: An essential motive to learn. Contemporary Educational Psychology, 25(1), 82-91. https://doi.org/10.1006/ceps.1999.1016

Publisher's Note Springer Nature remains neutral with regard to jurisdictional claims in published maps and institutional affiliations.

Olivia Johnston is a Lecturer at Edith Cowan University, in Perth, Western Australia. Her research interests include ability grouping, teacher expectations, student voice, qualitative research methods and grounded theory. 
Helen Wildy is former Dean of Education at the University of Western Australia in Perth, Western Australia. Her research interest include educational leadership, school improvement and qualitative research.

Jennifer Shand is a Lecturer at the University of Western Australia in Perth, Western Australia. Her research interests include initial teacher education and English Curriculum education. 